\title{
José María Bustillos, casi incorpóreo
}

Juan Pascual Gay

El Colegio de San Luis

Resumen

Existen muy pocos datos acerca de la vida y obra de José María Bustillos (1866-1899). Este artículo pretende articular la información más o menos disponible, a fin de ofrecer una semblanza de un escritor que gozó del cariño y del fervor de muchos de sus compañeros de generación, como José Juan Tablada, Francisco M. Olaguíbel, Chucho Urueta o Bernardo Couto Castillo. Con todo, las escasas noticias prefiguran una personalidad sensible y sencilla que hizo de la poesía su actividad preferente hasta su muerte sobrevenida a los treinta y tres años de edad.

Palabras clave: decadentismo, modernismo, bohemia, poesía.

\section{Abstract}

There are very few data about life and work of José Maria Bustillos (1866-1899). This article seeks to articulate wore or less the information available to provide a semblance of a writer who enjoyed the love and fervor of many of his generation, like: José Juan Tablada, Francisco M. Olaguibel, Chucho Urueta or Bernardo Couto Castillo. With all, the little news foreshadow a simple and sensitive personality, this made poetry his preferred activity until his dead occurring at 33 years old.

Keywords: Decadentism, Modernism, Bohemianism, Poetry. 
$\mathrm{D}$ e José María Bustillos no hay sino delicadas y atentas semblanzas, trazadas por sus contemporáneos a partir del afecto y la admiración discreta. Uno pensaría que más que frente a un joven ya bien entrado en la segunda juventud, se está ante un adolescente que no quiere o no puede dejar de serlo, pero al que sus compañeros de bohemia tampoco le permiten dar ese paso definitivo hacia la madurez. Si Amado Nervo expresa que "entre los poetas jóvenes de México, Bustillos es el más delicado" (1991: 11), José Juan Tablada habla de "su enamorada musa en una bergerade de Sajonia” (1994: 83-84). Pepe Bustillos, o Pepe a secas, como le conocían sus amigos y contemporáneos, es un caso raro en el proscenio literario del fin de siglo en México. José Remedios Colón publicó en El Sol de Toluca, el 24 de febrero de 1952, una semblanza de José María Bustillos recuperada del cronista Ramón Pérez que, a su vez, en 2003, fue rescatada por Alfonso Sánchez Arteche para la revista La Colmena, de la Universidad Autónoma del Estado de México; en ese retrato se insiste en los rasgos referidos: "Era el poeta José María Bustillos, pulcramente vestido, de facciones delicadas, de mirada dura y de semblante noble que revelaba desde luego una finísima educación" (Colón en Sánchez, 2003: 15). También Tablada refiere la elegancia anacrónica de Bustillos: "Terciábase la capa espańola, calábase sobre los ojos el sombrero que algo tenía de chambergo y en tal guisa su silueta que se alejaba, me hacía retroceder un siglo, hacia el pasado virreinal" (1991: 114). Curiosamente hay pocas noticias sobre su vida, pero muchas referencias a su probidad y bonhomía, a su caballerosidad y aristocracia del espíritu; así lo retrata Luis G. Urbina:

No servía para luchar, para bracear en este río turbio en el que forcejeamos sus amigos. Él nos veía impasible, indiferente, estoico, convencido tal vez de la inutilidad de nuestro esfuerzo. Tendido en la hierba de la orilla, lleno de prematuro cansancio, nos lanzaba sus epigramas, nos entretenía, nos obligaba a reír en medio 
del combate. Porque bajo las doradas transparencias de su sátira, columbrábamos su encantadora ternura femenina.

Cuando la vida le hacía daño, no se encolerizaba, no reñía con ella, no la odiaba; se le quedaba mirando con sus ojos bondadosos, como tímido huérfano que quiere desagraviar a la madrastra. (1923: 174-175)

Bustillos tuvo una afinidad demasiado próxima a Luis G. Urbina como para pasarla por alto, hasta el punto en que los dos participaron de una misma sensibilidad poética. Dice Enrique González Martínez que "apenas José María Bustillos, a quien la vida no dejó pasar de un augurio malogrado, puede aspirar a la gloria de haber tenido orientaciones semejantes a las del autor de Lámparas en agonía" (1914: XX). La amistad entre Pepe y Luis está más que probada, entre otras cosas, por ese poema que el primero dedicó al segundo, "Nocturno de estío", que retoma las "mariposas" como motivo alusivo a la alegría de la vida que de la misma manera utilizó Urbina en su poesía:
Oh! Mistrerios sublimes; oh! Pasiones!
Oh! Sombras voluptuosas
Que haceis extremecer los corazones
Y convertís las muertas ilusiones,
—esas larvas sin luz - en mariposas!
(Bustillos, 1900: 83)

Los pocos datos que existen se deben a Inocente Peñaloza García, quien registra que Bustillos nació el 6 de septiembre de 1866 en Tacubaya y que falleció el 20 de junio de 1899 en Toluca; no alcanzó los 33 años; la muerte se lo llevó cuando recién había obtenido la plaza de catedrático del Instituto Científico y Literario, cargo que combinaba con su nombramiento como Director de la Biblioteca Pública Central del Estado de México. Apenas ejerció sus nombra- 
mientos puesto que había ocupado las respectivas plazas en 1898, el mismo año que surgió una de las revistas más emblemáticas de la actual Universidad Autónoma del Estado de México, el Boletín del Instituto Cientifico y Literario Porfirio Diaz, publicación mensual que desatendió su regularidad a partir de 1910, para desaparecer en 1947. La sección literaria del Boletín le rindió un homenaje al poeta, "In Memoriam. Ante la tumba de José María Bustillos", en 1902 (VV. AA., 1902: 125). Al principio, la publicación estuvo dirigida por Silviano Enríquez Correa y Agustín González Plata, pero sus páginas se llenaron pronto de las colaboraciones de otros destacados escritores del plantel como Francisco M. Olaguíbel, Juan B. Garza o el propio José María Bustillos. En esos últimos años de su vida, se relacionó a Bustillos con Margarita de la Peña, hermana de Rosario de la Peńa quien forma parte ya de la leyenda literaria de México al asociarse con Manuel Acuña, como afirma José Luis Martínez: "La historia de su relación con Rosario [de Manuel Acuña] pertenece ya a la leyenda. A la musa de nuestro romanticismo dedicará la mayor parte de sus últimos poemas y ella aparecerá, acaso injustamente, como la causa del suicidio del poeta" (Martínez en Acuña, 2004: XX). Sin embargo, Tablada contradice esta versión y más bien apostilla que se trataba de Rosario y no de su hermana Margarita de quien entonces era novio Pepe Bustillos: "donde vivía su novia, aquella misma Rosario Peña, célebre por su singular atractivo sobre los poetas de dos generaciones" (1994: 14).

La austeridad fue norma y hábito en los últimos años de la vida cotidiana de Bustillos, como relata Ramón Pérez: "El amable poeta ocupaba un departamento anexo a la biblioteca y sólo tenía como muebles los más indispensables para él, ya que no tenía arrestos de orgullo, pues se notaba muy resignado con su modestísima situación, no obstante contar con el afecto sin límites y protección del señor general José Vicente Villada” (Colón en Sánchez, 2003: 
16). Pepe ofreció la silva "Inmortales" al "Sr. General José Vicente Villada”, en sintonía con la poesía cívica y patriótica de tono romántico, pero que revela la deuda personal con el general:

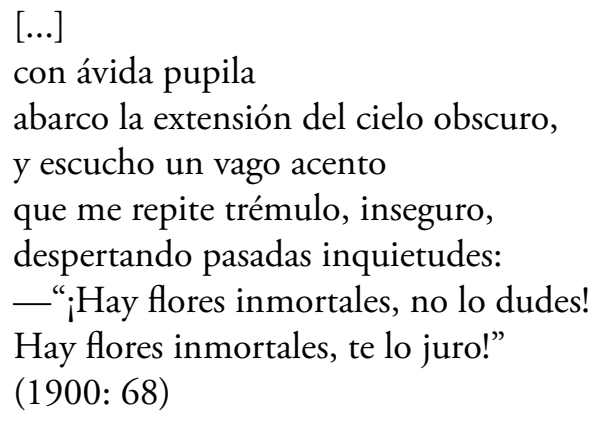

Una relación de la que da fe Rubén M. Campos al afirmar que "El gobernador del Estado de México, [...], se ha llevado a la ínsula una pléyade escritores entre los que destaca el poeta José María Bustillos, verdadero artista de la palabra que surgió en el Liceo Mexicano, donde publicó poemas encantadores" (1996: 60). Noticias elocuentes del temperamento discreto y tímido de Bustillos, más bien retraído, que no usó influencias para medrar y ascender en lo económico y social, talantes igualmente consignados por Campos al registrar que Bustillos "es afable, tímido, humilde, y estas cualidades lo han hecho alejarse de los intelectuales que mucho lo estiman" (60); pero también es una actitud reveladora de su compromiso con la poesía y el arte, una religión entonces de la que resultó un digno oficiante al destinar tanto su esfuerzo como su sensibilidad a su culto, sin buscar otras cosas que distrajeran su atención. Luis G. Urbina subraya el talante retraído de Pepe Bustillos: "La existencia de este insinuante músico del ensueño fue callada, escondida, sin aparato, sin ruido. Habitó el poeta una grata penumbra con salpicaduras de estrellas, olvidado del estrépito y desdeñoso de teatrales y ficticias apoteosis. Dentro de su pobre- 
za, aspiraba, como una flor oculta, la inmensa dicha de sentirse amado" (1923: 176). Más allá de otras cosas, hay que subrayar el compromiso suscrito por Bustillos, así como otros compañeros del modernismo mexicano como Bernardo Couto Castillo, Julio Ruelas o Jesús E. Valenzuela, de ofrendar su vida al arte. La muerte le llegó a José María Bustillos de un modo anodino, sin estridencias ni ruidos, como si su vida hubiera sido un acostumbramiento para ese momento definitivo. Inocente Peñaloza García cuenta así el deceso:

La vida del poeta Bustillos se extinguió rápidamente cuando fungía como director de la biblioteca pública, a consecuencia de un problema gástrico que no pudo ser controlado y que provocó su muerte prematura — tenía sólo 33 años- en el edificio de la biblioteca.

Su cuerpo fue sepultado en el panteón general de Toluca. En 1974, cuando se inauguró la Rotonda de los Hombres Ilustres, los restos de Bustillos no fueron trasladados - como sucedió con Garza, Villarello, Venegas y Cuenca- debido a que no era originario del Estado de México (2007: 23).

Sin embargo, Rubén M. Campos atribuye la muerte de Bustillos a su dipsomanía, algo que no parece muy fundado si nos atenemos a los testimonios que han dejado sus contemporáneos, en donde en ninguna parte, excepto en El bar, hay una información que avale tal afirmación. Quizás sea una estrategia de Campos para subrayar precisamente el talante trágico de su generación; con todo dice: "José M. Bustillos se extinguió ocultamente después de brillar un día a la par que Manuel Gutiérrez Nájera, otra lloradísima víctima del bar" (1996: 240). Luis G. Urbina, en un precioso librito titulado Hombre y libros, a propósito de la muerte del poeta, coincide en los excesos de Pepe Bustillos apenas apuntados por Campos; en una estampa escrita con motivo de su muerte, Urbina dice lo 
siguiente: "Tenía una pereza de enfermo para todas las cosas de la vida; una voluntad suave, dúctil, floja, dispuesta a ceder a la presión de cualquier mano. Por eso, cuando vino el Dolor lo maltrató tanto y le hizo llorar tan a menudo. Por eso, cuando vino la Poesía le arrancó sonidos tan hermosos y tan puros. Por eso, cuando vino la Tentación bebió él en su copa el licor amargo de los placeres fugitivos" (1923: 74).

Los dos últimos años de José María Bustillos son los más documentados y acerca de los que se poseen más noticias, como corresponde a quien ha decidido, después de una juventud bohemia y turbulenta, sentar cabeza e ingresar en un ámbito laboral más o menos estable. Sin embargo, los ańos previos a la llegada del poeta a Toluca estuvieron marcados por su militancia en la bohemia artístico-literaria finisecular que se vivió de manera efervescente y bulliciosa en la Ciudad de México; pero sobre todo es este movimiento, decadentista o modernista, al que se adhirió muy pronto, el que permite rastrear sus andanzas a partir de 1893. Con todo, Bustillos no tuvo participación alguna en las sucesivas polémicas decadentistas y modernistas que arreciaron en 1893 y, más tarde, en 1896 y 1898 . De hecho, Tablada en un artículo publicado en El Nacional, el 11 de junio de 1898, en donde daba la bienvenida a la publicación en ciernes Revista Moderna. Arte y Ciencia, al consignar la nómina de los redactores y colaboradores más conspicuos, omite el nombre de Bustillos: "El olmo secular de la justicia, el trono forestal, es un periódico exclusivamente literario que aparecerá en breve, y cuya redacción estará formada por artistas como Jesús Valenzuela, Julio Ruelas, Jesús Urueta, Balbino Dávalos, Ciro. B. Ceballos, Bernardo Couto, Rafael Delgado, Alberto Leduc, Francisco M. de Olaguíbel y Rubén M. Campos" (Tablada en Clark y Zavala, 2002: 315). Pero no quiere decir que no formara parte del cenáculo encabezado primero por José Juan Tablada y que, más tarde, fuera absorbido en torno a las páginas de la Revista Mo- 
derna, como antes lo fue por las de la Revista Azul. Campos, en El bar, indica que José María Bustillos integró aquella sociedad literaria, fundada por Manuel Ignacio Altamirano, llamada Liceo Mexicano, junto con otros poetas como Juan de Dios Peza, Luis G. Urbina o Enrique Fernández Granados, Fernangrana (Campos, 1996: 181). ${ }^{1}$ Todo indica que la bohemia, a la que era reacio Pepe Bustillos, no estaba completamente desterrada de sus hábitos, más bien la practicaba de manera esporádica, en ocasiones, debido a las reuniones de los miembros del Liceo Mexicano, como aquel cenáculo celebrado en el Sylvain, un restaurante de prestigio en la década última del siglo XIX, que solía congregar a artistas y escritores, como la rememorada por Campos a raíz de una invitación firmada por Joaquín D. Casasús y Ángel de Campo "para reinstalar la sociedad literaria que fundó el maestro don Ignacio M. Altamirano y de la que surgieron poetas y escritores de renombre, entre los que se contaban Luis G. Urbina, José M. Bustillos, Enrique Fernández Granados, Luis González Obregón, Antonio de la Peńa y Reyes, José P. Rivera, Ángel de Campo (Micrós), José Peón del Valle y otros cuyos nombres olvido" (Campos, 1996: 181). A estas sesiones celebradas una vez al mes, asistía puntual Bustillos, y acababan en una fiesta, en donde el bullicio, las anécdotas y las risas concluían una velada que había comenzado con la lectura de diferentes textos; a la hora de levantar la sesión "cada uno dejaba en una bandeja que tenía en sus manos un criado, cinco pesos del cubierto en la cena, y una propina para los criados, si era su voluntad" (183) a no ser que Casasús, como era frecuente, corrie-

${ }^{1}$ Belem Clark de Lara señala tres asociaciones literarias "importantes" en el periodo 1888-1910: "el Liceo Mexicano Científico y Literario (1885-1892), el Liceo Altamirano (1889-1905) y la Sociedad Literaria Cuathémoc (18911894)" y amplía la nómina de los escritores: Rafael Ángel de la Peña, Rafael Delgado, Emilio Rabasa, Manuel José Othón, Ángel Pola, Luis G. Urbina, Luis González Obregón, Balbino Dávalos, Victoriano Salado Álvarez, Ángel de Campo, además del propio Pepe Bustillos (Clark y Speckman, 2005: 36). 
ra con todos los gastos. Por su parte, Ciro B. Ceballos incluye a Bustillos dentro de otra tertulia no menos famosa y concurrida que tenía lugar en El Alhambra, decorado al estilo morisco en el interior y en el exterior mediante azulejos de estilo arábigo y colores lo suficientemente llamativos como para que atrajera la atención de los transeúntes. Gobernado por Vicente Mijares, El Alhambra congregaba en torno a sus mesas a "Manuel Larrańaga Portugal, Agustín Alfredo Núñez, Antonio de la Peña y Reyes, Arturo Paz, Salvador Dávalos, José Bustillos, Ricardo López Ochoa, Alfredo de la Portilla, Carlos Govantes, Francisco de la Garza Gutiérrez, Darío Balandrano, algunas veces Amado Nervo, algunas también Bernardo Couto Castillo y nosotros" (Ceballos, 2006: 105). Igualmente, Ceballos registra otro lugar al que asistía en ocasiones Pepe Bustillos, en donde se encontraban poetas y pintores, escritores y periodistas, sustituyendo así las habituales tabernas y bares; era el hogar de Eduardo Ruiz, diputado y procurador de la República, que impartía clases en la Escuela de Jurisprudencia. La tertulia habitualmente tenía lugar en la biblioteca del dueño de la casa que convidaba a sus invitados a café de Uruapan con "rajillas de queso"; allí llegaban "Antonio de la Peńa, Ezequiel Chávez, Balbino Dávalos, José Bustillos, Amado Nervo, etcétera" (392). A diferencia de las otras capillas más bien inclinadas a la bebida y los excesos de todo tipo, "la tertulia en aquella residencia, situada en la calle de Francisco Zarco, tenía particular amenidad, pues se leía poco, pasándose las horas de la reunión en alegre plática ininterrumpida por las risas suscitadas por los chistes ásperos del macabro crítico Antonio de la Peńa y Reyes" (393). Una vez concluida la reunión, los contertulios acudían al Salón Bach, donde acompañaban la cena con "un hermoso vaso de grueso cristal, rebosante en la espuma blanca de una cerveza, dorada como hirviente topacio". La noche, en ocasiones, la remataban los jóvenes poetas en casa 
de Balbino Dávalos, derrotados y exhaustos varaban en ese lugar como esos barcos que apenas alcanzan a atracar en el muelle.

Hay noticias de que entre 1890 y 1897 José María Bustillos ejerció diferentes oficios para mantenerse, y también a su familia; oficios que explican de alguna manera su relación esporádica con la cofradía decadente e, incluso, su ausencia en las sucesivas polémicas. Nervo, por ejemplo, consigna en 1895 que fue funcionario de "la Administración de Correos", motivo por el que estaba siempre ocupado yendo de un lado para el otro, sin apenas tener tiempo para dedicarse a la vida social y del mismo modo que en esos años rentaba un pequeño departamento en la calle de las Ratas número 6, en la Ciudad de México, a la que se refería para que sus conocidos y amigos no olvidaran su dirección como Seis ratas; y, poco más tarde, ejerció de boticario, motivo por el que concluye que " ¡Mal andaba su estro en aquella atmósfera llena de emanaciones de ungüentos, donde lo único que clamaba excelsior era... el álcali!" (Nervo, 1991: 11). Igualmente, Tablada recuerda el trabajo de Bustillos en las oficinas de Correos: "Desde aquella tarde en el Tívoli fuimos amigos y varias veces lo acompañé desde la Oficina de Correos donde trabajaba, contigua entonces al Museo Nacional, hasta el puente de Alvarado [...]" (Tablada, 1991: 144).

Seguramente, por esos mismos años comienza a compaginar sus trabajos con sus colaboraciones en diferentes revistas y publicaciones, en cuyas redacciones conoce a Tablada, quien ha dejado una nota de su primer encuentro:

Por aquella época conocí a ciertos compañeros que comenzaban a descollar en literatura. Fue Pepe Bustillos, hoy casi olvidado a pesar de su innegable mérito, el primer poeta que pude ver de cerca y tratar con cierta intimidad. Recuerdo haberlo conocido por conducto de Guillermo Vigil y Robles, también debutante literario, a la sazón y mi excompañero del Colegio Militar y que los tres fuimos a pasar la tarde al famoso Tívoli del Elíseo, bajo 
cuyos gigantescos árboles, de paisaje heroico, como diría un pintor académico, el romántico y delicado poeta recitó en obsequio nuestro, con su peculiar voz cálida, de trémulos acentos, el bellísimo poema suyo, "Las rocas del lago" (143).

Ese Colegio Militar donde estudiaron Tablada y Bustillos, les permitió acercarse e integrar en el grupo modernista a Julio Ruelas, quien recordaba una anécdota registrada por Jesús E. Valenzuela que algo inquiere acerca del carácter de Tablada: "Me acuerdo que un día me dijo Julio Ruelas: 'José Juan Tablada y yo fuimos expulsados del Colegio Militar: por falta de espíritu ídem'. Inmediatamente le manifesté a Tablada que por qué no me había dicho eso. 'Aunque sea verdad, Ruelas no debía contarlo', me contestó" (Valenzuela, 2001: 122). ${ }^{2}$ Bustillos ya había publicado entonces algunos poemas con desigual fortuna; pero lo notable es el retrato tan fin de siglo al que procede Tablada:

Delicado, frágil y vibrante, como el arpa eólica, parecía constante y dolorosamente conmovido por los efluvios todos del sentimiento y devastado materialmente por los ardientes vientos de la pasión. Tenía una bella cabeza de cabello rizado, palidez claustral, bellos ojos llenos de fiebre y de ensueño y labios naturalmente rojos, tanto como los de una mujer bajo el afeite; la fragilidad de su cuerpo denunciaba privaciones y estragos de sensibilidad hiperestesiada (1991: 143-144).

${ }^{2}$ Más adelante, en sus memorias, recuerda Valenzuela que "José Juan Tablada es un verdadero artista. Cuando estaba en el Colegio Militar publicaba, ilustrado por Julio Ruelas, un periodiquillo manuscrito y ponía de responsable a un muchacho, el más fuerte del colegio. Todos los que sentíanse heridos tenían que entendérselas con aquel Hércules y todo marchaba como balsa de aceite" (Valenzuela, 2001: 137). 
No es una casualidad que el propio Valenzuela consignara a Bustillos en la nómina de los nuevos poetas que siguieron la estela del Duque Job: "sólo Gutiérrez Nájera, con un instinto artístico incomparable, cultivaba la nueva cepa, apuntando detrás de él Urbina y Bustillos, con versos de amor, como el de Dafnis antes de ser iniciado en esas cosas, y de dolor como el que produce el roce de las espinas al cortar una flor” (2001: 118). Años más tarde, José Remedios Colón le entregó a Ramón Pérez unos apuntes acerca de Bustillos que coinciden en lo fundamental con el retrato abocetado por Tablada, publicados en El Sol de Toluca, el 24 de febrero de 1952:

Una mañana, mientras leía El Imparcial, que traía la noticia del incendio de un cajón de ropa en Toluca, se me acercó un caballero de mediana estatura, y tocándome la espalda me saludó y me condujo a su despacho. Era el poeta José María Bustillos, pulcramente vestido, de facciones delicadas, de mirada dura y de semblante noble que revelaba desde luego una finísima educación (Colón en Peñaloza, 2007: 23-24).

Parece que una de las aficiones más arraigadas en Pepe Bustillos era recitar sus propios versos con gran sentimiento y teatralidad en voz alta, "comenzaba a recitarme fragmentos de sus poemas, declamándolos patético y posesionándose de tal modo que su voz se solía entrecortarse como ahogando sollozos y humedecerse como lágrimas disueltas" (1991: 144), dice Tablada; mientras Ramón Pérez apostilla "ahí me recitaba con gran sentimiento y amor sus composiciones" (Peńaloza, 2007: 24). Amado Nervo proporciona una semblanza de Bustillos muy cercana en el tiempo a la de Tablada, ya que está fechada el 17 de febrero de 1895 :

-Pepe Bustillos..., ya lo conocerá usted: es un excelente muchacho que vive consagrado a su familia; que por ella trabaja sin 
descanso en la Administración de Correos y que tiene la singular genialidad de gozarse en referir a sus íntimos que anda de continuo enredado en nutrida red de lances y conflictos difíciles de resolver, nudos gordianos que por fortuna no existen sino en su imaginación (1991: 2011).

El carácter imaginativo y complicado de Bustillos se traducía en una poesía delicada y sutil, exigente y pulcra, que poco o nada tenía que ver con la vida diaria de su autor, como también dice Nervo:

En mi sentir, entre los poetas jóvenes de México, Bustillos es el más delicado.

Su inspiración, vigorosa siempre, enciérrase en moldes de exquisita pureza y encanto.

No es esa inspiración que asciende a lo excelso como Pegaso desbocado, sino la que sube lenta y suave como un perfume. No es su musa la tempestuosa virgen que ama el volcán ignívomo, el mar alborotado, el atronador torrente, sino la núbil y casta doncella que va en pos de mariposas por el Carmen florido, que corretea por la selva de pinos que semejan morisca columnata; que se contempla con coquetería en la linfa transparente y envía un beso a las estrellas tremulantes (1991: 11-12).

Dentro de la poética decadentista, hay acaso un rasgo más que lo sitúa en el centro de esa estética: la melancolía y la tristeza traducidas en una "plétora de imágenes de colorido admirable". De Bustillos se conserva un poemario, Versos 1884 a 1898, que proporciona su itinerario estético y poético. El volumen fue publicado ,de manera póstuma, en 1900 como un homenaje y una consideración del Estado de México; es un librito que recoge los poemas escritos a lo largo de esos 14 años, elocuente y fecundo, que opera como testimonio de la transición entre un romanticismo crepuscular, la aceptación del modernismo y la militancia decadente. El 
carácter póstumo explica algunas características del poemario, ya que carece de orden y distribución de partes, se acerca más a una compilación desbaratada y confusa que a un trabajo metódico y sistemático. Y de eso se trata Versos, de una recopilación de los diferentes poemas que Pepe Bustillos publicó en distintos periódicos y publicaciones periódicas. A pesar de la dispersión, es notable que diferentes compañeros del poeta aludan a títulos y versos de Bustillos como si su obra discreta y silenciosa, como el autor mismo, hubiera rebasado en mucho las expectativas depositadas en unas cuantas imágenes.

En ocasiones, se recaban noticias contradictorias respecto de la poesía de Pepe Bustillos, como cuando Peñaloza García indica que "González Pérez Gómez [...] señala dos poemas sueltos de aquella época: Las rocas del lago y La gruta de Cicalco" (2007: 24), cuando en realidad aparecen incluidos en el poemario citado. Precisamente, Tablada rememora que uno de los poemas que recitaba habitualmente Pepe era "Las rocas del lago" (1991: 143). Este poema debió de causar una honda impresión entre los modernistas, puesto que Rubén M. Campos lo comenta en su biografía literaria de la Ciudad de México:

"Las rocas del lago", una leyenda azteca, es un hermoso poema que bastaría para hacer el nombre de cualquier poeta, tiene otros muchos poemas que le conquistaron un eminente lugar en las letras [...] un lindísimo poema suyo, "Mariposas", hizo que el Duque Job, el príncipe de la poesía mexicana moderna, escribiera otro poema con ese mismo nombre que es una joya, como el primero, en nuestra literatura (1996: 60).

Algo parecido sucede con "El hachero" (Bustillos, 1900b: 185191), cuyo origen desvela Nervo al decir que la idea fue sugerida "por el seńor Licenciado Eduardo Ruiz, y dicho está con esto que el episodio es michoacano. Leyéndolo, percíbense las emanaciones 
aromadas de la zirinda llena de frescura; vuela la imaginación a aquellos tiempos en que el indomable guerrillero tremolaba en las escabrosidades de la sierra la bandera de la libertad" (1991: 12). El poema, que data de mayo 14 de 1892, tiene un aliento romántico como se colige de los versos del epígrafe procedentes de una tradición mexicana, de ahí su tono pintoresco que, en ocasiones, se acerca al costumbrismo. Las décimas se suceden de manera casi perfectas ajustándose a la "tristeza" expresada por una naturaleza al servicio del estado de ánimo del poeta; por eso dice también Amado Nervo que "no sé por qué al oírselos al poeta, que de tan bella manera los recita, paréceme escuchar el eterno susurro de los abetos, el chasquido del tronco que picotea el carpintero, el melancólico crujir de la hojarasca que se quiebra y el lejano y monótono rumor de la Zaráracua de iris glorioso" (1991: 12).

La poesía de Bustillos está dispersa en diferentes publicaciones y revistas. Hay constancia de sus colaboraciones en la Revista Azul, El Universal y la Revista Moderna. Arte y Ciencia, también en el Boletin del Instituto Cientifico y Literario, cuyas colaboraciones ya se han registrado. En cuanto a la Revista Azul, son siete los poemas publicados: "Nocturno de estío" (1894a: 37), "En la noche" (1894b: 135-136), "Ante el sepulcro de Manuel Gutiérrez Nájera” (1895 (15): 239), "Gota de agua” (1895a: 295), "En la muerte de Luis Gonzaga Ortiz" (1895c: 72), “Entonces” (1895d: 20) y "Cantares de Navidad" (1895e: 125-126). El poema "Ante el sepulcro de Manuel Gutiérrez Nájera" es el mismo que en la Revista Moderna, única colaboración de Bustillos en esta revista, se denomina "A Manuel Gutiérrez Nájera” (1900a: 40), un poema elegíaco dedicado a la muerte del director de la Revista Azul, y el mismo que se reproduce bajo el último título en Versos (1900b: 211-212). El soneto "En la muerte de Luis Gonzaga Ortiz" no se recogió en el volumen de sus poesías y, como el anterior, es un poema de tono elegíaco dedicado al también poeta: 
Llegué a la tumba trémulo, sombrío...

Y no pude rezar!... Las oraciones

Callaron, esperando las canciones

Del poeta del alba y del rocío.

¿Y el poeta... en silencio, solo, frío,

Inmóvil... ¿Es verdad?... ¿Las ilusiones,

El amor, el combate, ¡Las pasiones!

Son ¡ay! la espuma de impetuoso río?

Y lento me alejé. Sobre mi frente

Cayó la luz medrosa del Poniente,

Y pensé: “¿qué es la lucha sin victoria?”

Y entonces, en los sauces misteriosos,

Vibró un canto de ritmos temblorosos...

¡Cantó el ave inmortal, cantó la Gloria!

El Universal incluye cuatro composiciones poéticas de Bustillos: "Frío", publicado el 13 de septiembre de 1896; "Epitafio", en marzo 9 de 1896; "Amanece" el 18 de julio de 1897; y, finalmente, "Entonces", en abril 24 de 1898. Todos los poemas, a excepción de "Epitafio", se incluyeron igualmente en Versos. Pepe Bustillos recorrió rápidamente un itinerario que se inicia en el romanticismo y acaba con una poética de ademanes decadentes. Con todo, su expresión más lograda y depurada hay que asociarla con el modernismo. En este sentido, es relevante la presencia de Gutiérrez Nájera en su sensibilidad, un autor al que le dedica además del poema consignado, ese otro titulado "Gota de agua", en el que se adhiere al simbolismo como la corriente más ajustada para su época; los primeros versos no dejan lugar a dudas y, a la vez, operan como tributo al magisterio de Nájera: 
Coloqué en el florero un ramillete

De humedecidos nardos,

Y una gota de agua cayó entonces

En la mesa de mármol;

Y esa gota — diamante que la aurora

Tallara con sus manos-

Así me dijo, cuando ya el crepúsculo

Recogía su manto:

"No soy agua nomás; calla, no sabes

Lo que soy, lo que valgo:

Yo soy un firmamento: tengo auroras,

Y tempestades y astros!"

(1900b: 73)

Pero antes, el poeta tuvo que pulir y decantar su oficio en una atmósfera romántica que ya para finales de la década de los ochenta comenzaba a resultar anacrónica; de ese primer momento, que se corresponde a la adolescencia del autor, da cuenta cabal el poema que inaugura el libro Versos, fechado en 1889, "Preludio", en el que una voz adolescente, casi anińada, se somete al dictado de la poesía amorosa:

"Escribe versos", me dijo, en voz muy baja, el amor, $y$ yo que era un inocente se los pedí al corazón.

"Escribe versos", gritóme después, con trémula voz el lúgubre desengaño... ¡Y me los dio el corazón!

"Escribe versos", clamaron la angustia, el tedio, el dolor... ¡Y yo escribí tantos versos 
que agoté mi corazón!

(1900b: 1)

Octosílabos que recuerdan por momentos a Bécquer, pero que no consiguen esconder la pose del adolescente incapaz de ofrecer un sentimiento sincero y más bien se entrega a los lugares comunes de ese romanticismo y de esa edad. Con todo, se aprecian ya unos vocablos que caracterizan una manera de entender el mundo y que en literatura serán particularmente redituables pocos años después: la angustia, el dolor, el desengaño, pero sobre todo el tedio al que Guillermo Prieto había dedicado un artículo elocuente y persuasivo ańos antes, 1878, a lo que llama "el fastidio" y que, desde una indudable modernidad, asocia con una "enfermedad del alma” (1993: 396-404). La transición de Bustillos al modernismo es rápida y precisa; un año más tarde, ya presenta una poesía que, dejando a un lado el pesimismo habitual de un corazón adolorido y abandonado, habita espacios de penumbra y decadencia:

SOMBRA

¡Apágate crepúsculo! No anhelo tus sombras, tus reflejos, tus paisajes;

desprende la guirnalda de celajes con que decoras el azul del cielo; recoge el traje de purpúreo raso, y después avanzando majestuoso, arroja tu estandarte luminoso en el inmenso abismo del ocaso! [...] (1900b: 137)

Se trata de una estética en la que el autor se adentra más y más, como en "Hadas", poema de 1892: 
En las noches de insomnio, en esas noches

en que agoniza el alma,

y en que el tedio tenaz ciñe a la musa

una corona de amapolas blancas.

En esas noches lentas, en que todo

aletargado calla;

y solamente en el marmóreo estanque

turba el silencio al desbordarse el agua.

En esas noches en que mustia brilla

la luna solitaria;

— melancólico sol que arde encerrado

en un globo de nívea porcelana

[...] (1900b: 180)

Versos que recogen elementos ya significativos de la estética decadente: el ambiente crepuscular, la alusión a seres mágicos o maravillosos, pero sobre todo la referencia a la melancolía y la tristeza.

José María Bustillos no fue quizás el poeta más representativo del modernismo, tampoco ejerció cargos particularmente importantes tanto en el ámbito cultural como en el cultural y social. Con todo, su personalidad y su obra dejan un no sé qué de injusticia o de falta de atención inmerecida, no ya por el valor de su obra que, sin duda lo tiene, sino también por esos comentarios y recuerdos a la par admirados y afectuosos de sus compañeros de cenáculo. Se puede admitir que su timidez y su retraimiento le impidieron ocupar un lugar de relumbrón, pero esas mismas carencias permiten advertir un espíritu lo suficientemente sensible como para situar la poesía en su vida en un lugar central, a contracorriente de otras ambiciones y expectativas para las que la poesía no es sino un peldaño más; esta profesión de fe en el "arte por el arte", de la poesía reconvertida en religión, de una liturgia moral acorde con esa 
misma poética, sitúan a Pepe Bustillos en un lugar particular en el panteón literario de México. El hecho de que Urbina con justicia dijera de él que era "uno de esos seres intangibles, casi incorpóreos" (1923: 174), ni arrumba, ni minimiza su importancia. El recuerdo de Bustillos se debe a su poesía, no a su vida; a una vida que hizo de la poesía la vida misma.

\section{Bibliografía}

Acuña, Manuel, 2004, Obras: poesía y prosa, José Luis Martínez (pról.), México, Factoría.

Bustillos, José María, 1894a, "Nocturno de estío", Revista Azul, t. I, núm. 3, 20 de mayo, p. 37.

"En la noche", 1894b, Revista Azul, t. II, núm. 9, 30 de diciembre, pp. 135-136.

, 1895a, "Ante el sepulcro de Manuel Gutiérrez Nájera. Poesía leída por el señor don José Bustillos”, Revista Azul, t. II, núm. 15, 10 de febrero, p. 239.

, 1895b, "Gota de agua. A Manuel Gutiérrez Nájera”, Revista Azul, t. II, núm. 19, 10 de marzo, p. 295.

, 1895c, "En la muerte de Luis Gonzaga Ortiz", Revista $A z u l$, t. III, núm. 5, 2 de junio, p. 72.

, 1895d, "Entonces" (A Ricardo López Ochoa), Revista Azul, t. IV, núm. 2, 10 de noviembre, p. 20.

, 1895e, "Cantares de Navidad" (A mi hermana Adela), Revista Azul, t. IV, núm. 8, 22 de diciembre, pp. 125-126.

, 1896a, "Frío", El Universal, 13 de septiembre, p. 1.

, 1896b, "Epitafio", El Universal, 1 de noviembre, p. 1.

, 1897, “Amanece”, El Universal, 18 de julio, p. 1. 
, 1898, "Entonces", El Universal, 24 de abril, p. 1.

, 1900a, "A Manuel Gutiérrez Nájera”, Revista Moderna. Arte y Ciencia, t. III, núm. 3, $1^{\mathrm{a}}$ quincena de febrero, p. 40.

, 1900b, Versos, 1884 a 1898, Toluca, Oficina Tipográfica del Gobierno en la Escuela de Artes y Oficios.

Campos, Rubén M., 1996, El bar. La vida literaria de México en 1900. Serge I. Zaïteff (pról.), México, UNAM.

Ceballos, Ciro B., 2006, Panorama mexicano 1890-1910. (Memorias), Luz América Viveros Anaya (ed.), México, UNAM.

Clark de Lara, Belem, 2005, “¿Generaciones o constelaciones”, en B. Clark de Lara y Elisa Speckman Guerra (eds.), La República de las Letras. Asomos a la cultura escrita del México decimonónico. Ambientes, asociaciones y grupos. Movimientos, temas y géneros literarios, t. I, México, UNAM, pp. 11-46.

y Elisa Speckman Guerra (eds.), 2005, La República de las Letras. Asomos a la cultura escrita del México decimonónico. Ambientes, asociaciones y grupos. Movimientos, temas y géneros literarios, t. I, México, UNAM.

y Ana Laura Zavala (eds.), 2002, La construcción del modernismo (Antología), México, UNAM.

González Martínez, Enrique, 1914, "Luis G. Urbina”, en Luis G. Urbina, Lámparas en agonía, México, Librería Vda. De Ch. Bouret, pp. XI-XXVIII.

Martínez, José Luis, 2004, "Prólogo" a Manuel Acuña, Obras: poesía y prosa, México, Factoría, pp. IX-XXVIII.

Nervo, Amado, 1991, Obras completas, t. II, Francisco González Guerrero y Alfonso Méndez Plancarte (recop., pról. y notas), México, Aguilar.

Peñaloza García, Inocente, 2007, “José María Bustillos. Poeta del Instituto Científico y Literario”, La Colmena, núm. 55, pp. 2325 . 
Prieto, Guillermo, 1993, "Fastidio. Enfermedad del alma", en Cuadros de costumbres 2. Obras completas, t. III. Boris Rosen Jélomer (comp. y notas), Carlos Monsiváis (pról.), México, Conaculta, pp. 396-404.

Sánchez Arteche, Alfonso, 2003, "El Instituto hace cien años: algo de su vida cotidiana”, La Colmena, núm. 37, pp. 15-16.

Tablada, José Juan, 1991, La feria de la vida, México, Conaculta. , 1994, Critica literaria. Obras completas, t. V, Adriana Sandoval (ed., sel. y pról.), México, UNAM. , 2002, "La Revista Moderna”, en Belem Clark de Lara y Ana Laura Zavala (eds.), La construcción del modernismo (Antología), México, UNAM, pp. 315-316.

Urbina, Luis G., 1914, Lámparas en agonía, México, Librería Vda. de Ch. Bouret.

, 1923, Hombres y libros, México, El libro francés.

Valenzuela, Jesús E., 2001, Mis recuerdos. Manojo de rimas, Vicente Quirarte (pról. ed. y notas), México, Conaculta.

VV. AA., 1902, “In Memoriam. Ante la tumba de José María Bustillos", Boletín del Instituto Cientifico y Literario Porfirio Díaz, t. IV, Toluca, Tipografía del Gobierno en la Escuela de Artes y Oficios. 